\title{
КОНЦЕПТУАЛІЗАЦІЯ ДУХОВНИХ ЦІННОСТЕЙ В УКРАЇНСЬКОМУ НАУКОВОМУ ДИСКУРСІ Й ПОЕТИЧНОМУ МОВОМИСЛЕННІ
}

\author{
ОЛЬГА ЧЕРНЕНКО \\ Харківський національний педагогічний університет імені Г. С. Сковороди, \\ Харків - Україна \\ olsheva0609@ukr.net; ORCID: 0000-0001-9450-9147

\section{KONCEPTUALIZACJA WARTOŚCI DUCHOWYCH W UKRAIŃSKIM DYSKURSIE NAUKOWYM I POETYCKIM JĘZYKU MYŚLI}

\author{
OLGA CZERNENKO
}

Charkowski Narodowy Uniwersytet Pedagogiczny imienia Hryhorija Skoworody, Charków - Ukraina

STRESZCZENIE. Artykuł dotyczy konceptualizacji wartości duchowych. Są one rozpatrywane przez pryzmat ewolucji wartości od czasów starożytnej chińskiej myśli filozoficznej do rozkwitu współczesnych ukraińskich idei filozoficznych. Badaniu poddano również system wartości w ukraińskiej przestrzeni poetyckiej. Szczególną uwagę zwrócono na językowe aspekty kreatywności artystów, które wyróżniają wizerunki kobiet wśród innych cennych wartości w społeczeństwie. Określono środki stylistyczne, za pomocą których wizerunek kobiety jest zróżnicowany w twórczości W. Bojki i innych mistrzów słowa artystycznego.

Słowa kluczowe: obraz, kobieta, myśl filozoficzna, konceptualizacja, dyskurs naukowy, język myśli, poezja.

CONCEPTUALIZATION OF MORAL VALUES

IN UKRAINIAN SCIENTIFIC DISCOURSE AND POETIC LANGUAGE THINKING

\section{OLHA CHERNENKO}

H. S. Skovoroda Kharkiv National Pedagogical University, Kharkiv — Ukraine

ABSTRACT. The article deals with the conceptualization of the moral values. They have been considered through the prism of the evolution of values from the times of an ancient Chinese philosophical thought to the heyday of modern Ukrainian philosophical ideas. The existence of the values in the Ukrainian poetic space has been also researched. The emphasis has been placed on the linguistic aspects of creativity of artists, who distinguish the images of women among other valuable values in society. It has been determined, with the help of which language expressive means, a woman's image is differentiated in the works of V. Boyko and other masters of artistic word.

Key words: image, woman, philosophical thought, conceptualization, scientific discourse, language of thinking, poetry.

3 розвитком сучасної філософської думки на перший план виступає не лише людина як моральна й матеріальна цінність для суспільства, але і їі психоемоційний стан. Якщо представники німецької філософської школи (Кант, Фіхте, Ріккерт) були впевнені, що людина - це абсолютна цінність і за нею майбутнє філософії та суспільства зокрема, то відомий український мандрівний філософ Г. Сковорода ще у XVIII ст. акцентував увагу соціуму на внутрішньо- 
духовному аспекті особистості, стверджуючи, що серце є головною ланкою психоемоційного стану людини, бо гармонія в суспільстві можлива виключно тоді, коли в душі кожного окремого представника людства існує баланс між зовнішнім і внутрішнім світами. У цьому ракурсі духовність особистості розглядають не тільки як суто філософську категорію, але і як лінгвістичне поняття. Хоча духовність й асоціюється з моральністю, однак під час розгляду теорії духовності виробляються певні стереотипи. Перший стереотип бере свій початок від часів давньої китайської філософії (Лао-Дзи, Конфуцій, Мо-цзи): стверджувалося, що життя природи та людини підпорядковане не волі неба, а всезагальному закону “дао”, коли кожна річ, досягнувши певного рівня розвитку, перетворюється на протилежність. Так створювалися загальні закони суспільного буття, які чітко визначали, що є добро, а що зло ${ }^{1}$. Другий стереотип тяжіє до давньогрецької філософії й пов'язаний з іменами Арістотеля, Платона, Демокріта, у якій основна увага приділялася матеріальним благам, а духовне життя особистості відходило на другий план. Саме в цих благах убачалася головна ідея існування людства в суспільстві й світі загалом. Насамперед людину вважали скупченням атомів, але відрізнялася вона від інших живих істот наявністю душі. Душа - речовина, що містить дрібні, найбільш рухомі, вогненні атоми. Вона смертна, знищується зі смертю тіла, складається з двох частин: розумної (матеріальної), що в грудях, і нерозумної (не матеріальної), що розсіяна по всьому тілу. Пізнання, як уважав Демокріт, полягає в сприйнятті людиною дії на неї тіл і предметів через відповідні органи чуттів. Проникаючи в тіло людини, образи речей торкаються атомів душі та викликають у ній відповідні відчуття зовнішнього світу. Істинне ж пізнання досягається лише розумом².

Від класичної німецької філософської думки простежується теорія людиноцентризму, де людина стає центром Усесвіту, і саме навколо неї фокусуються всі інші природні явища й процеси. За ідеєю Фіхте, можна поєднати пізнання $\boldsymbol{i}$ приpoдy, людину $\boldsymbol{i}$ cвim $^{3}$. Людина стає сукупністю всіх моральних і матеріальних благ, найбільшою, абсолютною цінністю. Їі ж духовність - основний складник людського єства, його найважливіша частина. В основі духовності - сукупність тих морально-етичних і матеріальних норм та правил поведінки людини, що загальноприйняті в суспільстві й відрізняють “істоту розумну” від інших індивідів.

I, нарешті, четвертий стереотип, що більшою мірою віддзеркалює ідеї української та російської філософської думки стосовно існування внутрішнього та зовнішнього (морального й матеріального) світів особистості в єдиному гармонійному просторі. Інтелектуальному розвиткові людини українська філософія приділяє особливу увагу, що свідчить про домінування чуттєво-емоційної й інтелектуальної сфер над матеріальною. Звідси й постає, на думку О. Кубрякової, теорія концептів. За іiі визначенням, концепт є оперативною одиницею пам’яті, відображеною у психіці людини; одиницею ментальних чи психічних ресурсів свідомості й тієї інформаційної структури, що відбиває знання та досвід людини у вигляді “квантів знання" . Концепт - центральна одиниця когнітивної парадигми дослідження художніх текстів. Незважаючи на розробленість термінологічного апарату концептології, поняття художнього концепту ще осмислюється. Важливим є усвідомлення специфіки художнього концепту в зі-

${ }^{1}$ В. Г. Скотний, Філософія: історичний і систематичний курс, Київ 2005, с. 46.

${ }^{2}$ Там само, с. 56.

${ }^{3}$ Там само, с. 114.

${ }^{4}$ Е. С. Кубрякова, В. З. Демьянков, Ю. Г. Панкрац, Л. Ф. Лузина, Краткий словарь когнитивных терминов, под общ. ред. Е. С. Кубряковой, Москва 1997, с. 90-93. 
ставленні із концептами культури та мовними концептами ${ }^{5}$. Художній концепт народжується у творі, а продовжувати своє життя може поза його межами, адже він, з одного боку, репрезентує загальноприйняті знання, а з іншого - відображає суб' єктивний авторський чуттєвий досвід ${ }^{6}$. Ідеться про філософську модель концепту, а щодо лінгвістичної, то, на думку Л. Мовчан, центральним поняттям сучасної когнітивної лінгвістики $є$ концепт, що розглядається як одиниця концептуальної картини світу, відображеної у психіці людини. Основним методом дослідження в когнітивній лінгвістиці визнають концептуальний аналіз, однією з методик якого є фреймове моделювання. Фрейм - структура даних для репрезентації стереотипних ситуацій. Базисні фрейми відбивають узагальнені принципи організації інформації у свідомості людини ${ }^{7}$. Як наголошує Ю. Шепель, концепт як поняттєва категорія, на відміну від власне поняття, є прерогативою не самої філософіï, а радше лінгвософії. Якщо за поняттям стоїть реалія, речова субстанція, то за концептом не лише предметна віднесеність, предметний смисл, але й слово - ім'я реалії, слово - знак як певна інтелектуально осмислена сутність, значуща субстанція або знак смислу. Поняття зазвичай утілюється в найближчому значенні слова. Концепт - це й зміст поняття, і культурний смисл (а частіше - комплекс смислів) слова, навіяний реалією. В основі спроби класифікувати концепти - бажання конкретизувати поняття культурно-мовного концепту, а також полегшити процес опису концептів за допомогою віднесення їх до певного типу, порівн.: 1) семантичні, що розглядають концепти 3 позиції сфери їхнього вживання: акценти ставляться на смисловому значенні; 2) на основі вираження концептів, їхнього функціонування в мові ${ }^{8}$. Л. Лисиченко зазначає, що МКС - це інтерпретація світу людиною. У МКС інтегруються лінгвальні засоби вираження всіх картин світу, що для людей виражаються й об’ єктивуються через мову.

У науковій літературі вживають три терміни - мовна модель, мовна картина й мовний образ світу, які часто використовують як синоніми. Однак з огляду на структуру МКС вони відрізняються: мовна модель - логічний конструкт, мовна картина - iї лінгвальний еквівалент, збагачений за рахунок різноманітних зв'язків явищ у світі, і мовний образ - індивідуальна естетична сутність, що виявляється в індивідуальній картині світу, не завжди й не обов'язково художній: це залежить від різних спроможностей до мовної творчості ${ }^{9}$.

За принципом класифікації концептів відбувається певний розподіл цінностей на моральні (духовні) й матеріальні (тілесні). Разом із концептом і концептуальним аналізом виникає також поняття концептуалізації, визначення якої тяжіє більше до філософії, ніж до лінгвістики. На думку О. Селіванової, концептуалізація - один з процесів пізнавальної діяльності людини, що полягає в осмисленні й упорядкуванні результатів внутрішнього рефлексивного досві-

${ }^{5}$ Н. О. Смець, Художній концепт: моделі реконструкиї, [в:] „Науковий вісник Волинського національного університету ім. Лесі Українки. Філологічні науки. Мовознавство”, 2012, № 23 , c. 41 .

6 Там само, с. 42.

7 Л. Мовчан, Когнітивна лінгвістика: принципи аналізу мовного матеріалу, [в:] „Науковий вісник Східноєвропейського національного університету ім. Лесі Українки. Філологічні науки. Мовознавство", 2013, № 1, с. 78.

${ }^{8}$ Ю. О. Шепель, Щодо питання про культурний та мовний концепти, стереотип й національний характер, [в:] „Лінгвістика. Лінгвокультурологія. Іншомовний дискурс: складники, проблеми вивчення та навчання", 2012, № 9, с. 11.

9 Л. А. Лисиченко, Лексико-семантичний вимір мовної картини світу, Харків 2009, c. 12-13. 
ду людини й уявлень про об'єкти, явища дійсності та їхні ознаки. Результатом концептуалізації $є$ формування концептуальної системи, складниками якої $\epsilon$ концепти - інформаційні структури свідомості, різносубстратні за способами формування та представлення знань про певні об'єкти та явища. Концепти формуються на підставі вербальних і невербальних знань, набутих шляхом взаємодії п’яти психічних функцій свідомості (відчуттів, почуттів, мислення, інтуїції, трансценденції) і позасвідомого ${ }^{10}$. У цьому аспекті поетичне мислення має інший напрям і засади. Воно спрямоване на зосередження уваги читача на особистісних, психоемоційних інтенціях, тобто поетична мова належить до інтелектуально-пізнавальної сфери лінгвістики.

Т. Талько та Т. Власова вважають, що духовна культура є механізмом передачі нагромаджених суспільством різноманітних цінностей і традицій. Вона охоплює сферу духовного виробництва, а духовній культурі властиві певні особливості: вона історично зумовлена, фіксує національні особливості, включає загальнолюдські цінності ${ }^{11}$.

На думку Т. Космеди, сила, вага, значущість слова пояснює появу такого явища, як табу на слова, що називають життєво важливі поняття й реалії. У свідомості давніх українців критерієм добра стає не лише розум, але передусім серце як добро пов'язане не тільки з розумом, але й волею, бажанням, вірою ${ }^{12}$. У цьому сенсі мова поетичних творів теж є своєрідною концептуалізацією життєвих та морально-етичних настанов, вираженням духовного стану митця, його соціальних і духовних уподобань. Як зауважує А. Приходько, у когнітивній моделі вивчається людський інтелект, а мова визнається головним ментальним складником усієї інфраструктури мозку, інструментом мисленнєво-мовленнєвих процесів, засобом пізнання довкілля та позагенетичного передавання людського досвіду. У комунікативній парадигмі мову досліджують у зв'язку з їі роллю в умовах реальної мовленнєвої діяльності, де на перше місце висувається мовна особистість та іiі соціодискурсивна активність ${ }^{13}$. Поетичне мовомислення співіснує з духовною внутрішньою культурою особистості, що дає змогу розмірковувати про кожного майстра пера як окремого індивіда, а МКС розглядати крізь призму власне особистісних мовних і мисленнєвих реалій.

У поезії В. Бойка концептуалізація таких реалій відбувається завдяки блискуче виписаним жіночим образам, бо ставлення художника до жінки від вірша до вірша - це вияв ціннісно-життєвих орієнтирів. Кожен текст митця просякнутий любов’ю й шаною до слабкої статі. Палітра образів різнокольорова, поет уважає жінку найбільшим скарбом у світі, ставиться до неї бережливо, з повагою. Його вірші струмують ніжністю, теплом, подекуди виражають розпач через розставання або втрату коханої. Для нього важливий і зовнішній вигляд героїні, і їі душевний стан, і самопочуття, і ставлення жінки до довкілля. Цінністю крізь усю творчість В. Бойка проходить образ жінки - людини, берегині сімейного вогнища, тієї, яка продовжує людський рід, доньки, матері, коханої, по-

${ }^{10}$ О. О. Селіванова, Сучасна лінгвістика: термінологічна енциклопедія, Полтава 2006, c. 258 .

11 Т. І. Власова, Т. М. Талько, Духовні иңінності в умовах глобальних цүивілізаційних трансформацій, Дніпропетровськ 2009, с. 72.

${ }^{12}$ Т. Космеда, Аксіологічні аспекти прагмалінгвістики: формування і розвиток категорії оцінки, Львів 2000, с. 25.

13 А. М. Приходько, Когнітивно-комунікативний дуалізм сучасної парадигми лінгвістики, [в:] „Науковий вісник Волинського національного університету ім. Лесі Українки”, 2012, № 23, c. 192 . 
рівн.: ЖІНКА - ДОНЬКА: Я Вас любив, як донечку свою, / із мудрістю у слові, не в любові. / Я Вас беріг, як пісню солов'ю. / Отак собі жили у ній обоє ${ }^{14}$. ЖІНКА - КОХАНА: I десь од почілунку до сльози /дві зіроньки ставали дві ожини... / А що б я вдіяв проти лютих зим?! / Я Вас жалів. Жалів, немов дружину ${ }^{15}$. ЖІНКА - MATIP: Ви ще отут. Ізліва. Живете. / Нову оселю погляд Ваш засватав. / Я все хлоп'як. А білий світ росте. / Вас шанувати б, наче рідну матір... ${ }^{16}$. ЖІНКА - ПАМ'ЯТЬ: І все оче лиш для казок та віршів, / i то не я, а хтось забутий інший // твоӥх листів чека в глухе село. / Листам залишу їх сумнівну вартість, / а там: на сполох вдарять солов' 1 - / позичу в сина акварельні фарби / $і$ буду очі малювать твої ${ }^{17}$. ЖІНКА - МРІЯ: День як вечір. Вечір - ніченька. / Ніде дітись од сльоти. / Лиш собаки - друзі лічені / та іще твої листи. / Я до них озвуся вдосвіта. / Я із ними пожурюсь. / Ніби ніч прожив без дозволу / по чужім календарю. / Зайдеться сорока лементом / $i$ чкурне навтікача. / Не виходить в нас полеміка - / треба перекладача. / День як вечір. 3 ним пораджуся. / А чи може, навпаки?.. / 3 зарубіжного відрядження / повертаються шпаки ${ }^{18}$. У цих рядках простежуємо мотиви смутку, журби, жалю за минулим, поет переймається тим, що багато слів не сказано, дещо не зроблено. Лірика митця просякнута болем і тугою за нездійсненними мріями, за побаченням, якого не буде, образом коханої, яку він ніколи більше не зустріне. У свідомості ліричного героя зринає спомин про символ України - калину, що пригадується ще 3 дитинства й порівнюється у вірші $з$ дівчиною, яку поет, як і калину, не може забути, порівн.: ЖІНКА - ПАМ'ЯТЬ: Ти переходиш у пам'ять. / Я переходжу в осінь. / Світ переходить у пагін —/ дощику, дощику просить... ${ }^{19}$; Вже вечірнім людям поробилось сонно, / в кожної хмарини стало по зорі... / Лиш не спить калина, світиться червоно / із мого дитинства у чужім дворі ${ }^{20}$. ЖІНКА - РОЗПАЧ: Троянди три у стінах нічиїх / залишені, як в голодовку діти... / Ота, кому подарували їх, / доволі мала клопоту й без квітів. / Чи алібі потрібне їй було / для інших днів безпрограшно-святкових, / де світ рожевим так заволокло, / що чорним видававсь червоний колір? / Рожеву свічку муж згасив і ліг. / Біля порога витерти несила / три краплі крові між пір'їнок сивих — / троянди три у стінах нічиїх ${ }^{21}$. ЖІНКА - ДУМКА: Рядки дотичні до думок, / думки дотичні до колізій — / так, мов до сония понад лісом / дотичний предковічний мох... / У них вдивляюся, немов / у дзеркало під час гоління. / Які ж ми до словес голінні, / до клятв, обіиянок, промов!.. / Думки у вирій подались. / Слова - мов камені лежсачі. / А на столі від мами лист. / Чекає відповіді, й плаче

У Бойковій поезії часто функціонує займенник ти як звертання до рідного, того, хто може надихнути на написання віршів, задля кого $є$ сенс жити. Саме із жінкою ототожнює автор поетичні рядки про могутню силу слова, порівн.: ТИ - СЛОВО: Всіх, окрім себе, у тиші під сонщем любові / хай балакучим чути немає коли. / Доле зрадлива, дай мені вимовчать слово. / Сила і мудрість на різ-

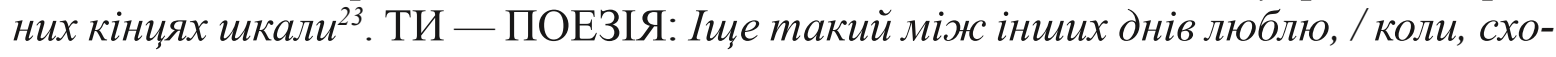

\footnotetext{
${ }^{14}$ В. С. Бойко, Зазимки, Харків 1990, с. 17.

15 Там само.

16 Там само.

17 Там само, с. 7.

${ }^{18}$ Там само, с. 16.

19 Там само, с. 41.

${ }^{20}$ Там само, с. 37.

${ }^{21}$ Там само, с. 61 .

${ }^{22}$ Там само, с. 65.

${ }^{23}$ Там само, с. 64.
} 
вавшись од турбот щоденних, / пишу, неначе зайчиків ловлю - / усі вони найсонячніші в мене. / I кожен прагне вирвати з пітьми / то профіль чийсь, то дим, то дальній берег - / устигни лиш - до серия все візьми, / а найдорожче поверни паперу... ${ }^{24}$. ТИ - ЗАВТРА: А завтра все буде, як завтра... / В учора - сьогоднішній біль / тече, наче річечка Ятрань... / - До завтра! - гукаю собі ${ }^{25}$. Тема неосяжності майбутнього, розуміння того, що бажана зустріч більше не відбудеться, наявна в ліриці поета, де постає ще одна абсолютна цінність світу - любов: ЖІНКА - ЗУСТРІЧ - НІКОЛИ: Неначе в різних НЛО / мчимо врізнобіч по орбіті, / а те, що звали білим світом, / вже білим снігом замело.../ I далина, мов глибина, / в якій лише всесвітній холод. / Орбіта все-таки одна. / Коли зустрінемось? Ніколи?!!26. ЖІНКА - ПРОЩАННЯ: Не впізнаю твоє лице / на випадковій фотокартиі. / Не признаюсь тобі про це / в листах, яким не написаться. / Кімната в темряву вроста, / гуде у ній порожнім глеком. / Отак, неначе сніг розтав, / а до весни іще далеко ${ }^{27}$. Поетове сокровенне виявляється в його ставленні до жінок, вони для В. Бойка й ті, хто може підтримати в складній ситуації, і ті, розставання з якими - нестерпний біль, i ті, поруч із якими він щасливий і розуміє, що життя продовжується: ТИ - ЖІНКА: Ти - жінка з свічкою у тихому вікні. / Я - твій неспокій в дальній стороні ${ }^{28}$; Мені потрібен місяць, що минув, / у ньому наші погляди стрічались, / з твого дитинства кінь приходив чалий, / мене губами теплими торкнув ${ }^{29}$; І кора березова зітхне, // відчувши березоля чистий подих. / Іще, напевно, згадуєи мене / собі на смуток. І мені на подив ${ }^{30}$; Щось є таємне в спалаху кульбаб, // коли вже не весна і ще не літо, / немов луна лоскоче по губах / дівочих уст nереданим привітом ${ }^{31}$; Плисти у пісні иілу ніч до рана, / розгойдану зеленими вітрами, / уперше бути богом, чортом, паном / опісля Йвана та й перед Купалом. / I вийти в сад, в очах твойх блукати, / себе у них назавще відшукати. / I зрозуміти вдосвіта обом нам: / єдину істину зовуть л ю б о в' ю, / це біля неї, мов біля багаття, / і я, і ти, і наша біла хата, // де під вікном червоная калина / вогнем незгасним сонще запалила ${ }^{32}$.

У поетичних рядках А. Малишка, як й у В. Бойка, простежуємо неосяжне, усепереможне кохання до жінки як до особливого створіння, найціннішої земної істоти, берегині, яка дарує чоловікові щастя, любов, тепло, надію: ЖІНКА - КРАСА: ... I кіс твойх нетронутий янтар, / і помах рук, коли ідеш додому. / Не ляже все на полотні німому, / усе вмістити я не маю чар. / Зерно відкину, небеса і сушу / $і$ навіть камню я скажу: прости. / Щоб тільки милої велику душу / у незвичайній фарбі донести ${ }^{33}$. ЖІНКА - НАДІЯ: Ти мене накличешся ночами, / несучи розлуку за плечами, / i навиглядаєшся одна. / Настраждаєшся в своїи надї, / пригадаєш літа молодії, / рідну землю, де гуде війна ${ }^{34}$. ЖІНКА - ЩАСТЯ: Нашу любов, як омріяну зірку, / не кину вітру, не дам на розлу-

\footnotetext{
${ }^{24}$ Там само, с. 69.

${ }^{25}$ Там само, с. 39.

${ }^{26}$ Там само, с. 18.

${ }^{27}$ Там само, с. 27.

${ }^{28}$ В. С. Бойко, Обличчям до багаття, Харків 1984, с. 17.

${ }^{29}$ Там само, с. 26.

${ }^{30}$ Там само, с. 26

31 Там само, с. 32.

${ }^{32}$ Там само, с. 33.

${ }^{33}$ А. Малишко, Зерно і камінь..., [в:] Оріон золотий: Любовна лірика українських поетів,

${ }^{34}$ Там само, с. 118.
} Київ 1986, с. 117. 
ку. / Народиш синів мені добру п'ятірку, / спасибі за щастя. Прости за мукуз3. ЖІНКА - СВІТЛО: ...Щоб у мене зоря влюбилася, / а у тебе за брата грім, / шоб тобі вся земля світилася / так, як ти у житті моїм ${ }^{36}$. ЖІНКА - КОХАННЯ: Я забув, щзо й плачуть з поиілунку, / щзо й хороше слово є рідня, / ждав твойх очей, немов рятунку, / посмішки твоєї, наче дня. / Дні за днями $і$ за літом літо, / три, й чотири, й n'ять предовгих літ. / Буйне серие, снами не сповите, / погляд твій несло, як заповіт. / Всі мої сподіванки й надї̈, / слова ивіт, посіяний колись, / і розлуки, й весни молодії / в погляді твоєму заплелись. / $С$ в любові гіркота й порада, / може, в інших - зайва похвала, / а твоя ж людська ласкава звада / вже мене навік оповила ${ }^{37}$.

У віршах Д. Павличка наявна невимовна туга, рядки його ліричних поезій пронизані сумом і болем утрат. Але попри все він продовжує кохати, бо це й справді чи не єдиний дар у світі, порівн.: ЖІНКА - ГРІХОВНИЦЯ: Моя грiховнице пречиста, / моя лілеє на багні, / чужі обійми, як намиста, / ти познімала при мені. / ...А я тебе кохати буду / за те, що не упала ти / ні у потворну безвість бруду, / ні у нудоту чистоти. / За те, щяо ти взяла у змія / i принесла мені той плід, / в котрім була нужда і мрія, / $і$ молодість на сотні літ ${ }^{38}$. Для Д. Павличка в образі жінки виражені найщиріші почуття, у його інтимній ліриці помітні спільні з Бойковими творами риси: гострі й чіткі епітети, влучні метафори, крізь які простежуємо стрімкі й чутливі, але в той же час пристрасні й бурхливі почуття.

В. Бойку, як і Д. Павличку, притаманні точні й чіткі вирази, що відрізняє їхню риму від Малишкової - мелодійної та легкої, наче дмухання вітерця: ЖІНКА - ДРУЖИНА: Минулося кохання вечорове, / невинні почілунки відивіли. / Ти досі без моєї похвали / обходилась, ясна моя любове. / Творив я іншим гімни і хули, / для інших мав римовані промови, - для тебе мав я слово лиш прозове, / та вільно в ньому почуття жили. взнак у траві, / розкинувши долоні для обіймів. / А лінія грудей і рук ї̈ / творила образ лука в ту хвилину. / Я на зап'ястя тятиву напнув, / здавивщи пружну непокору лука. // Живої зброї вигини тугі / я гладив, наче перед поєдинком ${ }^{40}$. ЖІНКА - ДОРОГА: Найдовша з усіх доріг — / дорога твого приходу. / Найбільша з усіх таємнииь - / таємниия твого обличчя. / Ми прощаємося на день, / ніби розходимось на віки. / I твій слід на моєму сериі / поглиблюють кожні очі ${ }^{41}$. ЖІНКА - ВОГОНЬ: Я буду на світі, / Допоки незнане світло / В обличчі твоєму світить. / Я житиму доти, / Допоки горіти буде / Долоні твоєї дотик42.

Поезія ж Ліни Костенко, на відміну від чоловічої, завжди по-жіночому прямолінійна й проста. Якщо жінка щось вирішила, то відмовити ії неможливо. Ïї душевний потенціал, внутрішньо-моральні настанови сильніші від чоловічих, стрункіші. І в їі віршах все по-буденному чесно, відкрито й тужливо, напр.: ЖІНКА - ГРІХ: Грішниия я. Полюбила чужого. / Долі моєї пекуча жого! / Буде гроза! Потім буде тиша. / Жінка твоя. Але я твоїма. / Десь ти живеш по дорозі в Святошино. / Душу мою без тебе спустошено. / Оче дожилася - з бурі та з клекоту, / оце дожилася - до сліз, до лепету. / Всесвіт. Проблеми. Траге-

\footnotetext{
${ }^{35}$ Там само.

${ }^{36}$ Там само, с. 119.

37 Там само, с. 120.

${ }^{38}$ Там само, с. 158-159.

39 Там само, с. 160.

${ }^{40}$ Там само, c. 161 .

${ }^{41}$ Там само, с. 162.

${ }^{42}$ Там само, с. 162.
} 
дій поденщина. / А я закохалася. Сказано - женщина ни мене отямся і отям / така любов буває раз в ніколи / вона ж промчить над зламаним життям / за нею ж будуть бігти видноколи / вона ж порве нам спокій до струни / вона ж слова поспалює вустами / спини мене спини і схамени / ще поки можу думати востаннє / ще поки можу але вже не можу / настала черга й на мою зорю / чи біля тебе душу відморожу / чи біля тебе полум'ям

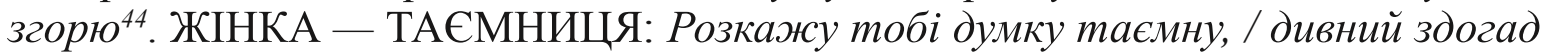
мене обпік: / я лишуся в сериі твоєму / на сьогодні, на завтра, навік. / I минатиме час, нанизавши / сотні вражень, імен $і$ краӥн, - / на сьогодні, на завтра, назавжди! - / ти залишишся в сериі моїм. / А чому? То чудна теорема, / на яку ти мене прирік. / То все разом, а ти - окремо. / I сьогодні, і завтра, й навік ${ }^{45}$. ЖІНКА - ЛЮБОВ: Маю день, маю мить, маю вічність собі на остачу. / Мала щастя своє, проміняла його на біду. / Голубими дощами сто раз над тобою заплачу. / Гіачинтовим сонием сто раз над тобою зійду. / Ми з тобою такі безборонні одне перед одним. / Ця любов була схожа на таӥнство перших причасть. / Кожен ранок був ніччю. Кожна ніч була передоднем. / Кожен день був жагучим чуттям передщасть. / А тепер... Що тепер? Моє серие навіки стерпне. / На пожежах печалі я пам'ять свою обпалю. / Якби ти знав, як солодко, нестерпно / $і$ як спочатку я тебе люблю! ${ }^{46}$.

3 поданих вище рядків зрозуміло, що творчість В. Бойка тяжіє до поетичного мовомислення Д. Павличка, а художнє слово Л. Костенко споріднене з віршовими рядками А. Малишка. Зазначимо також, що для В. Бойка жінка - духовна й соціокультурна істота. У Бойкових поезіях образ жінки виражений крізь призму соціальних подій, що робить його ще більш яскравим і виразним.

Отже, розвиток наукової думки й поетичного мовомислення в Україні відбувається досить стрімко. На перший план і в науці, і в поезії висуваються ціннісні духовні орієнтири. Вони стають рушійною силою не тільки для окремого індивіда, але й для суспільства загалом.

\section{Список використаної літератури}

Бойко В. С., Зазимки, Харків 1990.

Бойко В. С., Обличчям до багаття, Харків 1984.

Власова Т. І., Талько Т. М., Духовні цінності в умовах глобальних иивілізаиійних трансформаиій, Дніпропетровськ 2009.

Смець Н. О., Художній концепт: моделі реконструкиії, [в:] „Науковий вісник Волинського національного університету ім. Лесі Українки”, 2012, № 23, с. 41-42.

Космеда Т., Аксіологічні аспекти прагмалінгвістики: формування і розвиток категорії оцінки, Львів 2000.

Кубрякова Е. С., Демьянков В. З., Панкрац Ю. Г., Лузина Л. Ф., Краткий словарь когнитивныхх терминов, под общ. ред. Е. С. Кубряковой, Москва 1997.

Лисиченко Л. А., Лексико-семантичний вимір мовної картини світу, Харків 2009.

Малишко А., Зерно і камінь..., [в:] Оріон золотий: Любовна лірика украӥнських поетів, Київ 1986, с. 117-119.

Мовчан Л., Когнітивна лінгвістика: принципи аналізу мовного матеріалу, [в:] „Науковий вісник Східноєвропейського національного університету ім. Лесі Українки. Філологічні науки. Мовознавство", 2013, № 1, с. 78-79.

\footnotetext{
${ }^{43}$ Там само, с. 180.

${ }^{44}$ Там само, с. 181.

${ }^{45}$ Там само.

${ }^{46}$ Там само, с. 183.
} 
Приходько А. М., Когнітивно-комунікативний дуалізм сучасної парадигми лінгвістики, [в:] „Науковий вісник Волинського національного університету ім. Лесі Українки. Філологічні науки. Мовознавство”, 2012, № 23, с. 191-197.

Селіванова О. О., Сучасна лінгвістика: термінологічна енциклопедія, Полтава 2006.

Скотний В. Г., Філософія: історичний і систематичний курс, Київ 2005.

Шепель Ю. О., Щодо питання про культурний та мовний концепти, стереотип й національний характер, [в:] „Лінгвістика. Лінгвокультурологія. Іншомовний дискурс: складники, проблеми вивчення та навчання”, 2012, № 9, с. 15-20.

\section{Spysok vykorystanoi literatury [References]}

Boiko V. S., Zazymky [Zazymky], Kharkiv 1990.

Boiko V. S., Oblychchiam do bahattia [By Face to Fire], Kharkiv 1984.

Vlasova T. I., Talko T. M., Dukhovni tsinnosti v umovakh hlobalnykh tsyvilizatsiinykh transformatsii [Spiritual Values under Conditions of Global Transformations], Dnipropetrovsk 2009.

Yemets N. O., Khudozhnii kontsept: modeli rekonstruktsii [Fiction Concept: Models of Reconstruction], [v:] „Naukovyi visnyk Volynskoho natsionalnoho universytetu im. Lesi Ukrainky", 2012, № 23, s. 41-42.

Kosmeda T., Aksiolohichni aspekty prahmalinhvistyky: formuvannia i rozvytok katehorii otsinky [Axiological Aspects of Pragmalinguistics: Formation and Development of Estimation Category], Lviv 2000.

Kubryakova E. S., Dem'yankov V. Z., Pankracz Yu. G., Luzina L. F., Kratkij slovar' kognitivnyh terminov [Concise Dictionary of Cognitive Terms], pod obshh. red. E. S. Kubryakovoj, Moskva 1997.

Lysychenko L. A., Leksyko-semantychnyi vymir movnoi kartyny svitu [Lexico-Semantic Dimension of World Language Image], Kharkiv 2009.

Malyshko A., Zerno i kamin... [Grain and Stone], [v:] Orion zolotyi: Liubovna liryka ukrainskykh poetiv, Kyiv 1986, s. 117-119.

Movchan L., Kohnityvna linhvistyka: pryntsypy analizu movnoho materialu [Cognitive Linguistics: Principle of Analysis of Language Material], [v:] „Naukovyi visnyk Skhidnoievropeiskoho natsionalnoho universytetu im. Lesi Ukrainky. Filolohichni nauky. Movoznavstvo", 2013, № 1, s. 78-79.

Prykhodko A. M., Kohnityvno-komunikatyvnyi dualizm suchasnoi paradyhmy linhvistyky [Cognitive Communicative Dualism of Modern Linguistic Paradigm], [v:] „Naukovyi visnyk Volynskoho natsionalnoho universytetu im. Lesi Ukrainky. Filolohichni nauky. Movoznavstvo", 2012, № 23, s. 191-197.

Selivanova O. O., Suchasna linhvistyka: terminolohichna entsyklopediia [Modern Linguistics: Terminological Encyclopedia], Poltava 2006.

Skotnyi V. H., Filosofiia: istorychnyi i systematychnyi kurs [Philosophy: Historical and Systematic Course], Kyiv 2005.

Shepel Yu. O., Shchodo pytannia pro kulturnyi ta movnyi kontsepty, stereotyp y natsionalnyi kharakter [To the Question on Cultural and Linguistic Concepts, Stereotypes and National Character], [v:] „Linhvistyka. Linhvokulturolohiia. Inshomovnyi dyskurs: skladnyky, problemy vyvchennia ta navchannia”, 2012, № 9, s. 15-20. 